Genetic manipulation

\section{Rifkin strikes against gene transfer experiments}

\section{Washington}

ANTI-genetic engineering activist Jeremy Rifkin once again thrust recombinant DNA research in the United States under the spotlight of national attention last week. Rifkin's lobbying organization, the Foundation on Economic Trends, together with the Humane Society of the United States, has filed a suit in the district court here to halt gene-transfer experiments being carried out in livestock by the US Department of Agriculture (USDA). The plaintiffs allege that the experiments are a violation of the ethical canons of civilization and represent a new form of cruelty to animals.

The experiments entail injecting fusion genes that include the DNA structural sequence of the human growth hormone

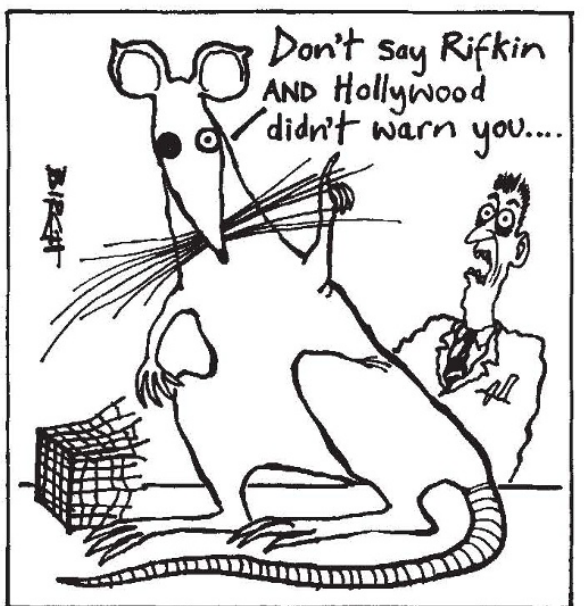

into the fertilized eggs of sheep and pigs. When similar experiments are done with mice, some of the resulting animals express the human gene, and so grow larger and faster than normal mice (see Science 222, $809 ; 1983)$, The new work is a collaborative effort between Dr Ralph Brinster of the University of Pennsylvania Veterinary School and a group under Dr Vernon Pursel at USDA's agricultural research centre at Beltsville, Maryland.

While the human origin of the growth hormone sequence doubtless added to the public's fascination, Rifkin makes clear that his objects apply to transferring any foreign genetic material into the germ line of a species. It would be morally objectionable to transfer animal genes to humans, Rifkin says, and it is similarly objectionable to transfer human genes to animals. Furthermore, the biological stability of the species would be threatened if farmers switched in large numbers to "super animals" containing genes from other species. Rifkin believes there would be undesirable economic and evironmental consequences of the general use of genetically engineered livestock, with small farmers being forced out of the market and higher prices being passed on to the consumer. The Humane Society of the United States argues that physiological imbalances in genetically engineered animals would cause suffering.

Brinster, evidently feeling besieged, was trying to avoid the press last week, but wants the public to understand the possible benefits from the research. Apart from the prospect of better and cheaper meat and other animal products, gene transfer experiments hold great potential for cancer research, especially with Leder's recent demonstration that transgenic animals can inherit a propensity for particular cancers.

The human growth hormone sequence was used simply because it is well studied and is easier to detect in mice than the rat sequence originally used (see Nature 300 , $611 ; 1982$ ). Despite the difficulties of working with opaque eggs, the livestock system is working well. Brinster declines, however, to discuss preliminary findings

\section{Dutch universities}

THE Dutch universities will feel the pinch again next year, despite ministry of education figures that make it appear that university research spending has increased substantially. The ministry has achieved this sleight of hand by recalculating the time a university teacher spends on research.

In the 1970s, the ministry assumed that natural scientists in the Netherlands spent 36 per cent of their time on research - and their salaries were debited from the research budget in proportion. In 1985, however, the assumption will be very different; research time is estimated to be 44 per cent of duties on average, varying from 18 per cent in academic hospitals to 61 per cent in mathematics.

The result in the nominal university science budget is that what appears to be an increase, from DFl 1,452 million ( $£ 341$ million) in 1984 to DFl 1,796 million ( $£ 418$ million) in 1985 , is actually a decrease in real terms. If the budget is calculated using the 36 per cent research time figure, and compared at constant prices with the 1980 figures, it appears that the 1983 budget was just 93 per cent of the 1980 figure, the 1984 budget 92 per cent and next year down to 91 per cent. Of course the new calculations (which put the 1985 university research figure at 114 per cent of that in 1980 , at constant prices) do not make more money available to research, and by raising the apparent budget make it more vulnerable to until definitive results are ready for publication. So far "several hundred" eggs have been injected with the growth hormone fusion gene; if successful, the experiments will allow further work on the processing of gene products, because livestock animals provide larger tissue samples than mice.

USDA officials concede that Rifkin's challenge will probably be pursued by the court, but they have not yet studied the litigation in detail. Whichever side loses in the first round of the action is certain to appeal, and the case could drag on for a long time.

The three causes of action cited by the plantiffs refer to the creation of federal common law nuisance and violations of the National Environmental Policy Act and the Administrative Procedure Act. In essence, the claim is that USDA's animal breeding programme is at odds with policies approved by Congress in other areas, and that USDA has not adequately considered other strategies or the impacts of its programmes. Rifkin is also trying to introduce an amendment to the guidelines used by the Recombinant DNA Advisory Committee of the National Institutes of Health, which would restrict research in the area and which due to be discussed later this month. In the meantime, the research continues.

Tim Beardsley

\title{
Small print conceals more cuts
}

the threat of cuts at cabinet level. However, the re-calculation was merely for administrative convenience, and not a policy matter, a government spokesman said last week. The new research-time figures are based on careful surveys of what Dutch researchers actually do, and are not pulled out of a hat. Interestingly, though, they conflict with lower fractions generally assumed in other countries. In Britain, for instance, the University Grants Committee estimates research time to be just over 30 per cent of duties.

Robert Walgate - Total Dutch spending on research and development will increase slightly next year to DFl 8,132 million ( $£ 1,890$ million), according to recent government predictions. Government spending will be DFl 3,882 million ( $£ 903$ million), a slightly lower fraction of the Gross National Product (GNP) (0.97 per cent) than last year $(0.98$ per cent $)$, but still larger than in the years 1980-83 (0.90-0.93 per cent). Industry will spend DFl 3,800 million ( $£ 884$ million), the government estimates, and another DFl 450 million ( $£ 105$ million) will go to international projects.

Dutch research spending is therefore below the European Economic Community average as a fraction of GNP, but only 3 per cent of the Dutch research and development budget is spent on defence. This compares with 33 per cent in France. 